\title{
Penerapan Citra Terkompresi Pada Segmentasi Citra Menggunakan Algoritme K-MEANS
}

\author{
I Wayan Angga Wijaya Kusuma ${ }^{1}$, Rossy Lydia Ellyana ${ }^{2}$ \\ Jurusan Teknik Elektro ,Universitas Widya Dharma \\ Klaten \\ anggaelectro@yahoo. $\mathrm{com}^{1}$ ochiellyana@gmail. $\mathrm{com}^{2}$
}

\begin{abstract}
Nowadays, an image is not only a documentation of events. One area that requires image processing is radiology. In radiology there is a medical image required by doctors and researchers to be processed for patient analysis. One of the important problems in image processing and pattern recognition is image segmentation into homogeneous areas. Segmentation in medical images will result in a medical image with area boundaries that are important information for analysis. This research applies K-Means algorithm to MRI (Magnetic Resonance Imaging) image segmentation. The input image used is the image of MRI (brain and breast) has gone through the compression stage. This compression process is done with the aim of reducing memory usage but the critical information content of MRI image is still maintained. The image of the segmentation result is evaluated through performance test using GCE, VOI, $M S E$, and PSNR parameters. The proposed K-Means algorithm for the segmentation process is able to work on images with JPG, $P N G$, and BMP extensions. The results showed that the VOI value of BMP image has a greater similarity value with the original image than JPG or PNG. The GCE and MSE values of the three extensions are also relatively small, nearly 0 , indicating the image of the segmentation has a large similarity value with the original image. Further BMP also has the largest PSNR value compared with JPG and PNG.
\end{abstract}

Intisari - Suatu citra tidak hanya sebagai dokumentasi dari kejadian yang pernah dialami. Salah satu bidang yang memerlukan pengolahan citra (image processing) adalah pada bidang kedokteran yaitu radiologi. Pada bidang radiologi terdapat citra medis atau medical image yang diperlukan oleh dokter maupun peneliti untuk kebutuhan analisis pasien. Salah satu permasalahan penting dalam bidang pengolahan citra dan pengenalan pola adalah segmentasi citra ke dalam area homogen. Segmentasi pada citra medis akan menghasilkan citra medis yang disertai batasan-batasan area yang merupakan ciri penting karena dapat menggali informasi untuk pengenalan pola guna keperluan analisis. Penelitian ini menerapkan algoritme K-Means pada segmentasi citra medis MRI (Magnetic Resonance Imaging). Citra input yang digunakan adalah citra MRIotak dan payudara yang sudah melalui tahap kompresi. Proses kompresi ini dilakukan dengan tujuan mengurangi penggunaan memori namun kadungan informasi penting citra MRI masih tetap terjaga. Citra hasil segmentasi dievaluasi melalui uji performansi menggunakan parameter GCE, VOI, MSE, dan PSNR. Algoritme K-Means yang diusulkan untuk proses segmentasi mampu bekerja pada citra dengan ekstensi JPG, PNG, mapun ekstensi BMP. Dari hasil penelitian, nilai VOI citra BMP memiliki nilai kesamaan yang lebih besar dengan citra aslinya dibandingkan citra JPG maupun citra PNG. Nilai GCE dan MSE yang dihasilkan dari ketiga ekstensi tersebut juga relatif kecil, mendekati 0 . Ini menandakan citra hasil segmentasi memiliki nilai kesamaan yang yang besar dengan citra aslinya. Selanjutnya citra BMP juga memiliki nilai PSNR yang paling besar dibandingkan dengan citra JPG dan citra PNG.

\section{Kata Kunci - Citra, Medis, Segmentasi, K-Means}

\section{Pendahuluan}

Meningkatnya perkembangan ilmu pengetahuan menghasilkan perkembangan teknologi yang berkembang pesat di bidang kedokteran, penginderaan bumi jarak jauh, meteorologi dan geofisika, robotika, dan dalam bidang yang lain. Bidang-bidang tersebut membutuhkan suatu teknologi kamera yang dapat digunakan untuk merekam keadaan yang diperlukan untuk kebutuhan analisis sehingga memungkinkan peneliti informasi yang diperlukan. Output dari kamera ini berupa citra (image).

Dalam perkembangannya suatu citra tidak hanya sebagai dokumentasi dari kejadian yang pernah dialami. Namun kini suatu citra dapat menjadi alat bantu analisis di segala bidang. Citra inilah yang nantinya akan dianalisis untuk mendapatkan informasi yang berguna. Teknologi pengolahan citra dapat masuk ke berbagai bidang seperti kedokteran, industri, pertanian, geologi, kelautan, dan sebagainya. Kehadiran teknologi pengolahan citra memberikan kemajuan yang sangat luar biasa pada bidangbidang tersebut.

Salah satu bidang kedokteran yang memerlukan pengolahan citra (image processing) adalah bidang radiologi [1]. Pada bidang radiologi terdapat citra medis (medical image) yang diperlukan oleh dokter maupun peneliti untuk kebutuhan analisis pasien. Citra medis adalah suatu pola atau gambar dua dimensi bagian dalam tubuh manusia yang digunakan oleh ahli kesehatan untuk mendeteksi dan menganalisis penyakit pasien. Pengolahan citra medis dapat digunakan untuk deteksi tumor atau kanker Rahim, identifikasi penyakit paru-paru, identifikasi penyakit hati, identifikasi penyakit tulang, segmentasi tulang dari otot lainnya, klasifikasi gigi, dan analisis citra mikroskopis. Untuk memperoleh citra ini banyak metode yang digunakan seperti Magnetic resonance Imaging (MRI), X-Ray, Ultrasonography (USG), Endoscopy, Computed Tomography (CT-Scan) dan Nuclear Medicine.

Pada bidang radiologi citra yang sering digunakan saat ini adalah citra Magnetic resonance Imaging (MRI) [1] Keunggulan citra MRI adalah kemampuan menampilkan detail anatomi secara jelas dalam berbagai potongan (multiplanar) tanpa mengubah posisi pasien. MRI dapat memvisualisasi struktur internal secara rinci [2]. MRI menghasilkan kontras yang baik sehinggga berguna pada 
pencitraan otak, otot, jantung, dan kanker dibandingkan dengan teknik pencitraan medis yang lain [2]. Citra MRI ini akan digunakan oleh dokter ataupun peneliti untuk melakukan analisis ada tidaknya suatu tumor, kanker, atau kelainan pada pasien.

Salah satu permasalahan penting dalam bidang pengolahan citra dan pengenalan pola adalah segmentasi citra ke dalam area homogen. Ekstraksi ciri dan segmentasi citra merupakan langkah awal yang sangat diperlukan dalam analisis citra. Segmentasi citra merupakan kegiatan yang sangat diperlukan dalam usaha memahami ciri citra secara lengkap [3]. Keakuratan segmentasi menentukan keberhasilan dalam analisis isi suatu citra.

Segmentasi pada citra medis akan menghasilkan citra medis yang disertai batasan-batasan area yang merupakan ciri penting karena dapat menggali informasi untuk pengenalan pola guna keperluan analisis.

Tujuan utama segmentasi adalah membagi citra ke dalam bagian-bagian yang mempunyai korelasi kuat dengan adanya objek-objek di dalam citra [3]. Citra medis yang tersegmentasi dengan baik akan didapatkan informasi batasan-batasan area dengan jelas, misalnya untuk keperluan deteksi sel tumor atau kelainan (lesi) yang lain pada pasien. Informasi ini sangat membantu tenaga medis secara objektif dan akurat untuk melakukan analisis, diagnosis, perencanaan pengobatan, dan tindakan medis yang diperlukan.

Berdasarkan uraian-uraian di depan, pada penelitian ini diusulkan algoritme K-Means untuk melakukan proses segmentasi pada citra MRI. K-Means merupakan salah satu teknik yang digunakan dalam segmentasi citra berbasis clustering [1]. Algoritme $K$-Means termasuk partitioning clustering yang memisahkan data ke $\mathrm{k}$ daerah bagian yang terpisah. Algoritme K-Means sangat terkenal karena kemudahan dan kemampuannya untuk mengklaster data besar dan data outlier dengan sangat cepat [1].

Rumusan masalah pada penelitian ini adalah bagaimana menerapkan algoritme $K$-Means pada segmentasi citra medis MRI (Magnetic Resonance Imaging). Citra hasil segmentasi dapat dianalisis secara akurat sehingga tidak merugikan pihak pasien ataupun pihak medis.

Batasan masalah pada penelitian ini adalah citra medis yang digunakan pada penelitian ini adalah citra MRI otak dan payudara baik dalam kondisi normal atau mengalami lesi (gangguan/kelainan). Citra hasil segmentasi dievaluasi melalui uji performansi menggunakan parameter GCE, VOI, MSE, dan PSNR.

Tujuan dari penelitian ini adalah membuat program menggunakan Matlab untuk proses segmentasi citra sehingga proses analisis dapat lebih akurat dan tidak merugikan pasien atapun pihak medis.

\section{TINJAUAN PUSTAKA DAN DASAR TEORI}

\subsection{Tinjauan Pustaka}

Penelitian tentang segmentasi citra menggunakan algoritme $K$-Means sudah banyak dilakukan diantaranya penelitian yang dilakukan oleh Nurhasanah (2011) [2] mengemukakan tentang segementasi jaringan otak putih, jaringan otak abu-abu, dan cairan otak dari citra MRI menggunakan teknik K-Means clustering. Algoritme $K$ Means clustering dipilih karena sederhana, mudah diimplementasikan, dan mampu menangani data outlier.
Penelitian berikutnya dilakukan oleh Jipkate dan Gohokar (2012) [4] membandingkan algoritme segmentasi citra $K$ Means dan Fuzzy C-Means Clustering. Algoritme yang dikembangkan di MATLAB untuk analisis dan dikomparasi. $K$-Means Clustering menghasilkan akurasi yang cukup tinggi dan membutuhkan waktu perhitungan cukup singkat. Fuzzy $c$-means menghasilkan hasil yang lebih bagus dari $K$-Means, namun membutuhkan lebih banyak waktu perhitungan dari $K$-Means karena langkah-langkah perhitungan fuzzy terlibat dalam algoritme.

Samma dan Salam [5] mengusulkan segmentasi citra berdasarkan adaptif algoritme $K$-Means clustering. Metode yang diusulkan mencoba mengembangkan algoritme $K$ Means untuk mendapatkan kinerja tinggi dan efisiensi. Selain itu, memecahkan sejumlah pemilihan model dengan menentukan jumlah kluster menggunakan dataset dari gambar dengan ukuran frame dan nilai absolut antara sarana, dan langkah-langkah tambahan untuk konvergensi langkah dalam algoritme $K$-Means ditambahkan.

Preeti Panwar, Girdhar Gopal, dan Rakesh Kumar [6] membandingkan segmentasi berbasis warna dengan algoritme $K$-Means clustering dan thresholding. Metode $K$ Means menggunakan klaster partisi. Algoritme K-Means clustering digunakan untuk mempartisi sebuah citra menjadi k kluster. K-Means clustering dan thresholding digunakan dalam penelitian ini untuk perbandingan hasil segmentasi. Perbandingan kedua teknik ini didasarkan pada parameter segmentasi seperti MSE, PSNR dan NSR. MSE dan PSNR secara luas digunakan untuk mengukur tingkat distorsi citra karena mereka dapat mewakili keseluruhan tingkat kesalahan gray-level yang terkandung di seluruh citra.

Dengan menggunakan dua teknik ini, kinerja untuk citra yang berbeda disegmentasikan dengan menggunakan parameter seperti MSE, PSNR, dan SNR. Dari pengamatan yang ditunjukkan dalam penelitian ini, dapat disimpulkan bahwa teknik thresholding memberikan output dari dua segmen. Namun pada teknik K-Means, output dari berbagai segmen sesuai dengan ukuran kluster. Kinerja meningkat sesuai dengan ukuran klaster. Lebih banyak lagi ukuran kluster adalah persentase akurasi. MSE dan PSNR digunakan untuk mengukur kualitas rekonstruksi. Nilai PSNR dari empat citrar dalam $K$-Means clustering lebih tinggi dari thresholding dan nilai MSE lebih rendah.

\subsection{Dasar Teori}

\subsubsection{Citra Digital}

Citra digital merupakan sebuah larik (array) yang berisi nilai-nilai real maupun kompleks yang direpresentasikan dengan deretan bit tertentu [1]. Suatu citra digital didefinisikan sebagai fungsi $f(x, y)$ berukuran $\mathrm{M}$ baris dan $\mathrm{N}$ kolom, dengan $\mathrm{x}$ dan $\mathrm{y}$ adalah koordinat spasial, dan amplitude $f$ di titik koordinat $(x, y)$ dinamakan intensitas atau tingkat keabuan dari citra pada titik tersebut. Apabila nilai $\mathrm{x}, \mathrm{y}$, dan nilai amplitude $f$ secara keseluruhan berhingga (finite) dan bernilai diskrit maka dapat dikatakan bahwa citra tersebut adalah citra digital. Gambar 1 menunjukkan posisi koordinat citra digital. Gambar 2 menunjukkan ilustrasi dari citra digital. 


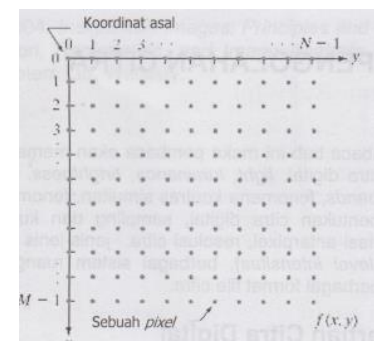

Gambar 1. Koordinat citra digital

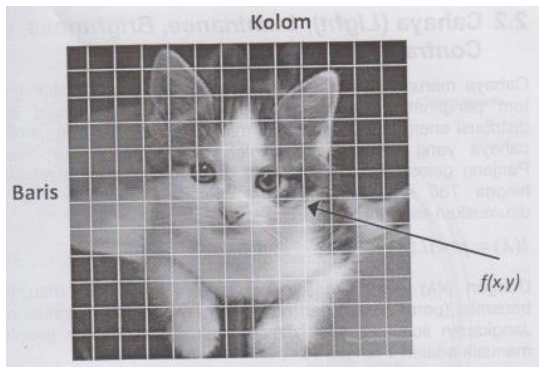

Gambar 2. Ilustrasi citra digital

a. Citra Warna

Setiap piksel pada citra warna mewakili warna yang merupakan kombinasi dari tiga warna dasar (Red, Green, Blue) [1]. Setiap warna dasar menggunakan penyimpanan 8 bit $=1$ byte, yang berarti setiap warna mempunyai gradasi sebanyak 255 warna. Berarti setiap piksel mempunyai kombinasi warna sebanyak 16 juta warna lebih. Itulah sebabnya format ini dinamakan true color karena mempunyai jumlah warna yang cukup besar sehingga bisa dikatakan hampir mencakup semua warna di alam.

Penyimpanan citra true color di dalam memori berbeda dengan citra grayscale. Setiap piksel dari citra grayscale 256 gradasi warna diwakili oleh 1 byte. Sedangkan 1 piksel citra true color diwakili oleh 3 byte, dimana masing-masing byte merepresentasikan warna merah (Red), hijau (Green), dan biru (Blue). Gambar 3 menunjukkan contoh penyimpanan citra warna di dalam memori.

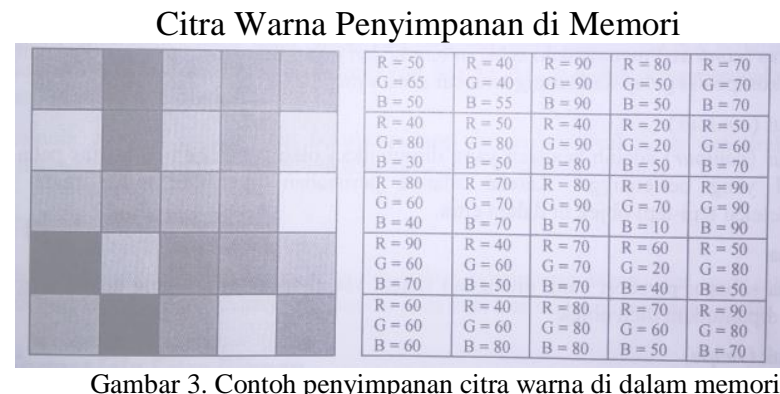

\section{b. Citra Grayscale}

Citra grayscale merupakan citra digital yang hanya memiliki satu nilai kanal pada setiap pikselnya, dengan kata lain bagian $\operatorname{Red}=$ Green $=$ Blue . Nilai tersebut digunakan untuk menunjukkan tingkat intesitas. Warna yang dimiliki adalah warna dari hitam, keabuan, dan putih. Tingkat keabuan merupakan warna abu dengan tingkatan dari hitam mendekati putih. Gambar 4 menunjukkan contoh citra grayscale.
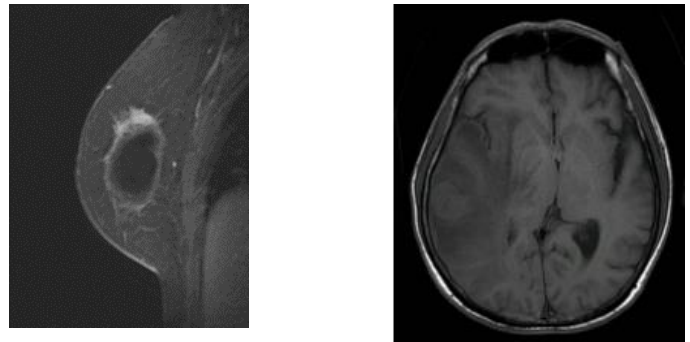

Gambar 4. Citra Grayscale

\section{c. Citra Biner}

Citra biner adalah citra digital yang hanya memiliki dua kemungkinan nilai piksel yaitu hitam dan putih [1]. Citra biner juga disebut sebagai citra $\mathrm{B} \& \mathrm{~W}$ (blck and white). Hanya dibutuhkan 1 bit untuk mewakili nilai dari setiap piksel dari citra biner.

Citra biner seringkali muncul sebagai hasil dari proses pengolahan seperti segmentasi, pengambangan, morfologi, maupun dithering. Gambar 5 menunjukkan contoh citra biner.

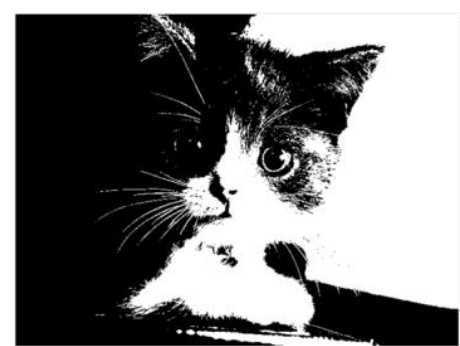

Gambar 5 . Citra Biner

\subsubsection{Citra Medis Magnetic Resonance Imaging (MRI)}

MRI adalah suatu alat kedokteran di bidang pemeriksaan diagnostik radiologi, yang menghasilkan rekaman gambar potongan penampang organ manusia dengan menggunakan medan magnet. Beberapa faktor kelebihan yang dimiliki oleh MRI adalah kemampuannya membuat potongan koronal, sagital, aksial tanpa banyak memanipulasi posisi tubuh pasien sehingga sangat sesuai untuk diagnostik jaringan lunak. Kualitas gambar MRI dapat memberikan gambaran detail tubuh manusia dengan perbedaan yang kontras, sehingga anatomi dan patologi jaringan tubuh dapat dievaluasi secara teliti. Gambar 6 menunjukkan alat MRI dan citra MRI.
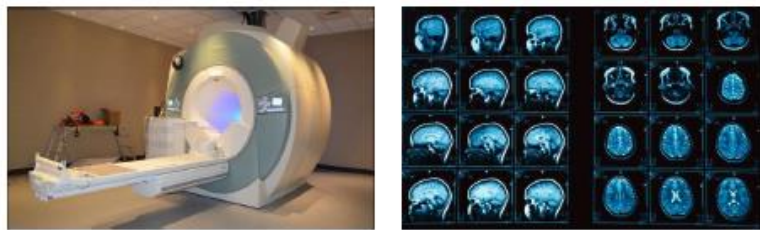

Gambar 6. Alat MRI dan Citra MRI

\subsubsection{Segmentasi Citra (Image Segmentation)}

Segmentasi merupakan teknik untuk membagi suatu citra menjadi beberapa daerah (region) dimana setiap daerah memiliki kemiripan atribut [1]. Segmentasi membagi citra ke dalam daerah intensitasnya masing-masing sehingga bias membedakan antara objek dan background-nya. Segmentasi citra bertujuan untuk membagi area-area yang homogen. 


\subsubsection{Segmentasi Berbasis Clustering}

Segmentasi berbasis kluster menggunakan data multidimensi untuk mengelompokkan piksel citra ke dalam beberapa kluster [1]. Pada umumnya piksel di kluster berdasarkan kedekatan jarak antar piksel.

Metode-metode dalam segmentasi berbasis clustering diantaranya adalah Iterasi, K-Means, Fuzzy C Means, Jaringan Syaraf Kohonen, dan berbagai teknik clustering lainnya [7].

\subsubsection{K-Means Clustering}

Algoritme $K$-Means mengelompokkan objek menjadi K kluster [1]. Metode ini akan mencari pusat kluster dan batasbatas cluster melalui proses perulangan (iterative). Kedekatan atau kemiripan (similarity) suatu objek dengan objek lain atau dengan pusat kluster dihitung dengan menggunakan fungsi jarak. Pada umumnya K-Means menggunakan jarak Euclidean untuk menghitung kemiripan tersebut. Berikut merupakan langkah-langkah algoritme $K$ Means [1]:

1. Inisialisasi $\mathrm{K}$ pusat kluster adalah $z_{1}(1)$, $z_{2}(1), \ldots . z_{k}(1)$. Pusat-pusat kluster ini biasanya dipilih secara sembarang dari sekumpulan data yang akan dikelompokkan.

2. Pada iterasi ke-k didistribusikan sampel data $\{x\}$ diantara $\mathrm{K}$ domain kluster, dengan menggunakan hubungan sebagain berikut :

$$
x \in S_{j}(k) \text { if }|| x-S_{j}(k)\left\|<|| x-S_{i}(k)\right\|
$$

Untuk semua $\mathrm{i}=1,2, \ldots . \mathrm{K}, \mathrm{i} \neq \mathrm{j}$, dengan $S_{j}(k)$ menyatakan himpunan sampel dengan pusat kluster adalah $z_{j}(k)$.

3. Dari hasil pada langkah 2, hitung pusat-pusat kluster baru $z_{j}(k+1), \mathrm{j}=1,2, \ldots \mathrm{K}$, sehingga jumlah seluruh jarak dari semua titik dalam $S_{j}(k)$ ke pusat kluster baru minimal. Dengan kata lain, pusat kluster baru $z_{j}(k+1)$ dihitung sehingga unjuk kerja indeks :

4.

$$
J_{j}=\sum_{x \in S_{j}(k)}\left\|x-z_{j}(k+1)\right\|^{2}, j=1,2, \ldots K(2)
$$

$z_{j}(k+1)$ yang meminimalkan persamaan diatas adalah dengan menyederhanakan nilai rata-rata dari sampel pada $S_{j}(k)$. Maka dari itu, pusat kluster baru ditunjukkan oleh:

$z_{j}(k+1)=\frac{1}{N_{j}} \sum_{x \in s_{j}(k)} x, j=1,2, \ldots K$

Dengan $N_{j}$ menyatakan jumlah sampel dalam $S_{j}(k)$.

5. Bila $z_{j}(k+1)=z_{j}(k)$ untuk $\mathrm{j}=1,2, \ldots \mathrm{K}$, maka algoritme telah konvergen dan proses berakhir. Bila tidak kembali ke langkah 2.
Gambar 7 menunjukkan ilustrasi proses pengelompokkan dari algoritme K-Means. Gambar 8 menunjukkan flowchart langkah-langkah algoritme $K$-Means.

The $K$-Means Clustering Method

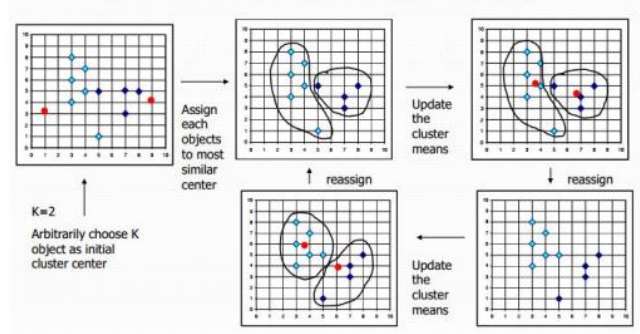

Gambar 7 . Proses pengelompokkan algoritme K-Means

\subsubsection{Distance (jarak)}

Jarak digunakan untuk menentukan tingkat kesamaan (similarity degree) atau ketidaksamaan (dissimilarity degree) dua vektor fitur [1]. Tingkat kesamaan berupa suatu nilai (score) dan berdasarkan skor tersebut dua vektor fitur akan dikatakan mirip atau tidak

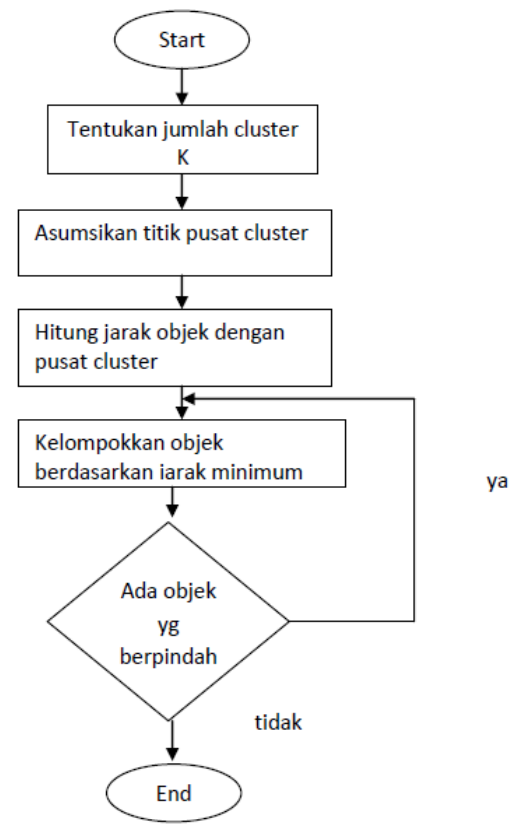

Gambar 8. Flowchart langkah-langkah algoritme K-Means

\subsubsection{Jarak Euclidean (Euclidean Distance)}

Euclidean distance adalah metrika yang paling sering digunakan untuk menghitung kesamaan 2 vektor [1]. Euclidean distance menghitung akar dari kuadrat perbedaan 2 vektor (root of square differences between 2 vectors). Berikut merupakan persamaan untuk menghitung Euclidean distance :

$$
d_{i j}=\sqrt{\sum_{k=1}^{n}\left(x_{i k}-x_{j k}\right)^{2}}
$$

\subsubsection{Parameter Pengukuran Uji Performansi}


Pengujian kualitas citra hasil segmentasi dapat diukur secara kuantitatif melalui uji performansi menggunakan parameter:

a. MSE (Mean Square Error), yaitu sigma dari jumlah error antara citra hasil segmentasi dengan citra asli. MSE dapat dihitung menggunakan persamaan berikut [7] :

$$
M S E=\frac{1}{M x N} \sum_{i=1}^{M} \sum_{j=1}^{N}\left(\left(f_{a}(i, j)-f_{b}(i, j)\right)^{2}\right.
$$

$\mathrm{M}$ dan $\mathrm{N}$ adalah ukuran panjang dan lebar citra. $f_{a}(i, j)=$ intensitas citra di titik $(i, j)$ citra asli $f_{b}(i, j)=$ intensitas citra di titik $(i, j)$ citra segmentasi

Semakin kecil nilai MSE, semakin bagus hasil peningkatan kualitas citra. Artinya, kualitas citra setelah mengalami peningkatan kualitas hampir sama dengan kualitas citra aslinya.

b. PSNR (Peak Signal to Noise Ratio). PSNR dapat dihirung menggunakan persamaan berikut [7] :

$$
P S N R=20 \log _{10} \frac{255}{M S E}
$$

Semakin besar nilai PSNR maka citra hasil peningkatan kualitas semakin mendekati citra aslinya. Sebaliknya, semakin kecil nilai PSNR semakin jelek kualitas citra hasil segementasi tersebut.

c. Variation of Information (VOI)

Parameter Variation of Information (VOI) mengukur jumlah kehilangan informasi dan mendapatkan informasi antara dua clustering, dan dengan demikian kira-kira mengukur sejauh mana satu pengelompokan dapat menjelaskan lainnya [8] [9] [10].

Variation of Information (VOI) mengukur jumlah kehilangan informasi dan mendapatkan informasi antara dua clustering, dan dengan demikian kira-kira mengukur sejauh mana satu pengelompokan dapat menjelaskan lainnya. Dengan nilai yang lebih rendah menunjukkan kesamaan yang lebih besar.

\section{d. Global Consistency Error (GCE)}

Parameter Global Consistency Error (GCE) adalah Segmentasi konsistensi berbasis Region, yang mengukur untuk mengukur konsistensi antara segmentasi citra berbeda granularities [8] [9] [10].

Global Consistency Error (GCE) mengukur kesalahan segmentasi mengambil dua segmentasi S1 dan S2 sebagai input, dan menghasilkan output bernilai nyata dalam rentang $[0:: 1]$ di mana nol menandakan tidak ada kesalahan.

\section{METOdOLOGI PENELITIAN}

Citra yang digunakan adalah Citra MRI Otak (Brain MRI) dan citra MRI payudara (Breast MRI) sejumlah 10 citra baik citra warna (color image) maupun citra grayscale (grayscale image). Citra MRI yang digunakan sudah melalui tahap kompresi. Proses kompresi ini dilakukan dengan tujuan mengurangi penggunaan memori namun kandungan informasi penting citra MRI masih tetap terjaga [11].

Metode yang digunakan dalam kompresi citra MRI adalah algortime $K$-Means [11]. $K$-means adalah salah satu teknik yang digunakan dalam segmentasi berbasis clustering Clustering termasuk ke dalam teknik lossy compression. Karena dengan tingkat kompresi yang tinggi, sehingga dapat menghemat banyak bandwidth.

Peralatan yang digunakan dalam penelitian ini adalah perangkat keras (hardware) berupa sebuah laptop dengan spesifikasi : Sistem Komputer : Core 2 duo T5870, Sistem Operasi : Microsoft Windows 7, dan Memori : 2GB RAM dan perangkat lunak (software) Matlab R2013A, microsoft office, serta software image processing adobe photoshop.

Tahapan segmentasi pada penelitian ini menggunakan Matlab yaitu :

Langkah 1 : Baca citra yang akan disegmentasi

$$
\begin{aligned}
& \text { im }=\text { imread ('Breast Normal.jpg'); } \\
& \text { figure(1), imshow(im); }
\end{aligned}
$$

Langkah 2 : proses checking citra input (citra warna atau citra grayscale)

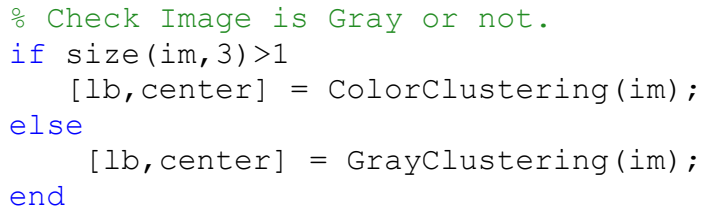

Untuk citra grayscale :

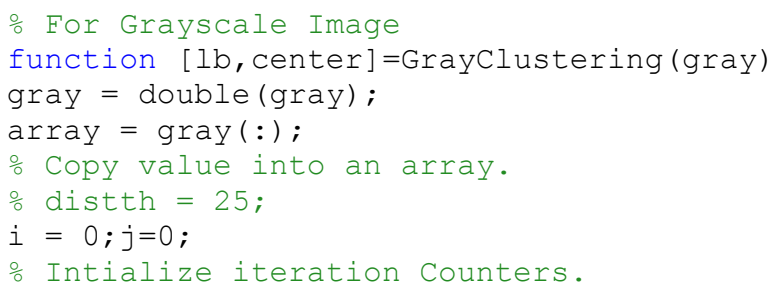

Untuk citra warna :

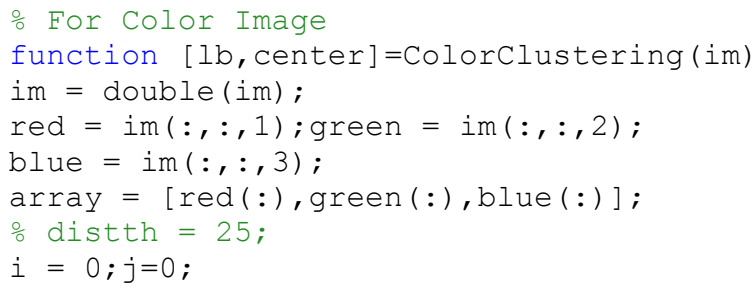

Langkah 3 : Pengelompokkan Warna dalam 'a*b*' Ruang Menggunakan $K$-Means Clustering

Untuk citra grayscale :

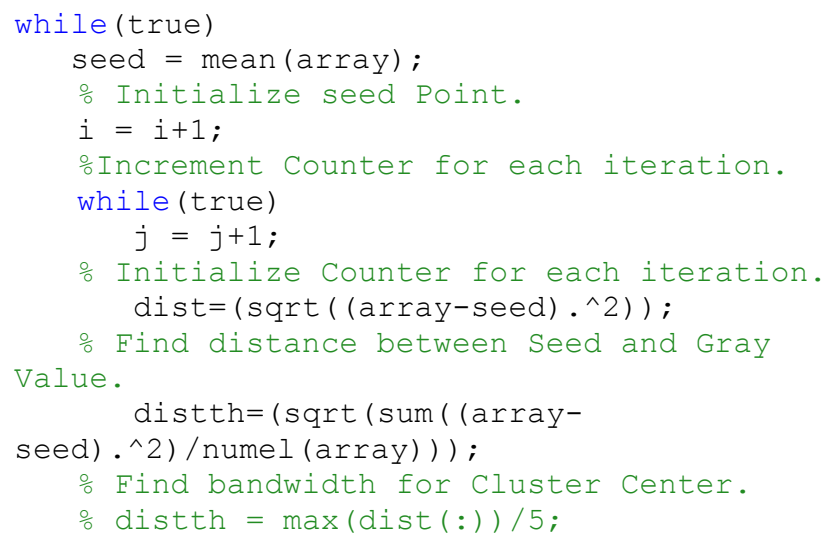


qualified = dist<distth;

\% Check values are in selected Bandwidth or not

newseed = mean (array (qualified));

\% Update mean.

Untuk citra warna :

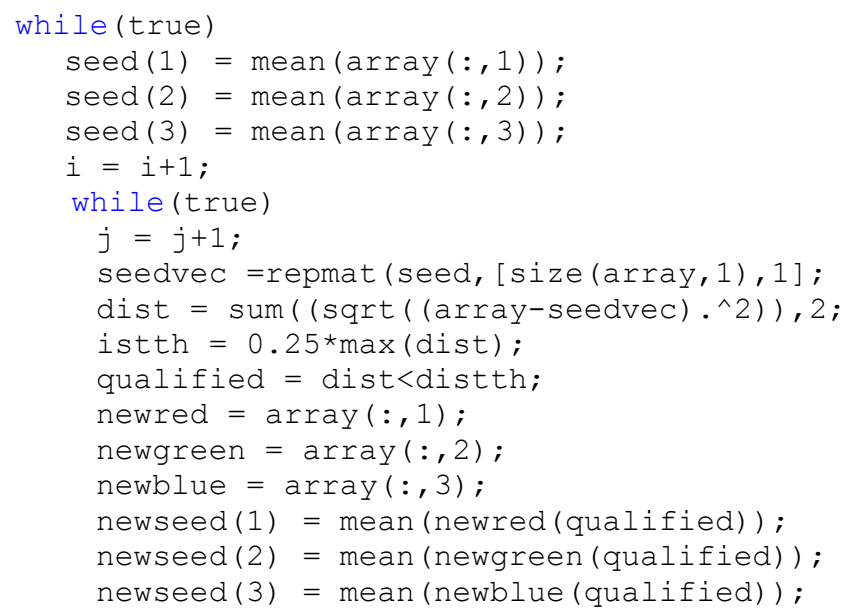

Langkah 4 : Label setiap piksel di citra menggunakan hasil dari $K$-Means

Citra Grayscale :

vector $=$ repmat $(\operatorname{gray}(:),[1$, numel (center) $])$; o Replicate vector for parallel operation. centers $=$ repmat (center, $[$ numel (gray), 1$])$; distance $=($ (vector-centers $\left.) \cdot{ }^{\wedge} 2\right)$;

\% Find distance between center and pixel value.

$[\sim, 1 \mathrm{~b}]=\min ($ distance, []$, 2)$;

\% Choose cluster index of minimum distance.

$1 \mathrm{~b}=$ reshape (1b, size (gray));

Reshape the labelled index vector.

Citra warna :

vecred=repmat $(\operatorname{red}(:),[1, \operatorname{size}(\operatorname{center}, 1)])$; vecgreen $=$

repmat (green (:), [1, size (center, 1) ] ; vecblue $=$ repmat $($ blue $(:),[1, \operatorname{size}($ center, 1) ]) ; distred $=($ vecred-

repmat (center $(:, 1)$ ', $[$ numel (red), 1])) .^2; distgreen $=($ vecgreen -

repmat (center $(:, 2)$ ', $[$ numel (red), 1])) .^2; distblue $=($ vecblue-

repmat (center $(:, 3)$ ', [ numel (red), 1])) .^2; distance $=$ sqrt (distred+distgreen+distblue); $[\sim$, label vector $]=\min ($ distance, []$, 2)$; $1 \mathrm{~b}=$ reshape (label vector, size(red));

Langkah 5 : Menampilkan citra segmentasi berdasarkan warna

figure (2), imshow (1b, []);

Hasil dari ketiga ekstensi tersebut kemudian dikomparasikan menggunakan parameter Variation of Information (VOI), Global Consistency Error (GCE), MSE (Mean Square Error) dan PSNR (Peak Signal to Noise Ratio). Berikut merupakan blok diagram dan potongan source code perancangan uji perfomansi segmentasi menggunakan Matlab :
1. Blok diagram menghitung Global Consistency Error (GCE) menggunakan Matlab pada Gambar 9.

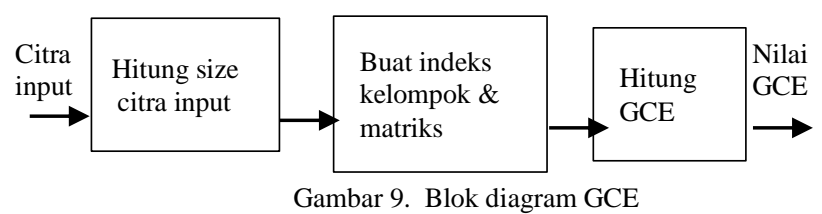

Berikut potongan source code menghitung GCE menggunakan Matlab :

global consistancy error (from BSDS ICCV 01 paper) ... lower $=>$ better

function gce $=$ global consistancy error $(\mathrm{n})$

$\mathrm{N}=\operatorname{sum}(\operatorname{sum}(\mathrm{n}))$;

marginal $1=\operatorname{sum}(n, 2)$;

marginal $2=\operatorname{sum}(\mathrm{n}, 1)$;

\% the hackery is to protect against cases

where some of the marginals are

\% zero (should never happen, but seems

to...)

$\mathrm{E} 1=1-\operatorname{sum}\left(\operatorname{sum}\left(\mathrm{n} \cdot{ }^{\star} \mathrm{n}, 2\right) . /\right.$ (marginal $1+$ (marginal $1==0)$ ) ) / N ; $\mathrm{E} 2=1-\overline{\operatorname{sum}}\left(\operatorname{sum}\left(\mathrm{n} \cdot{ }^{\star} \mathrm{n}, 1\right) . /\right.$ (marginal $2+$ (marginal $2==0)$ ) ) $/ \mathrm{N}$; gce $=\min (\mathrm{E} 1, \mathrm{E} 2)$

2. Blok diagram menghitung Variation of Information (VOI) menggunakan Matlab dijabarkan di Gambar 10.

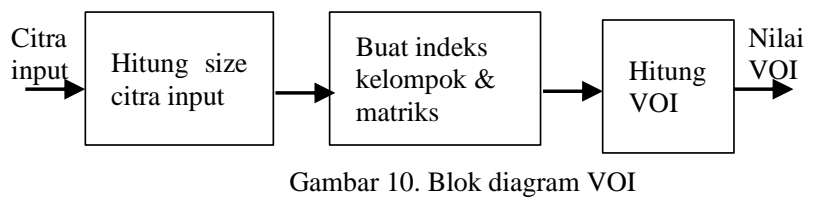

Berikut potongan source code mengitung VOI menggunakan Matlab :

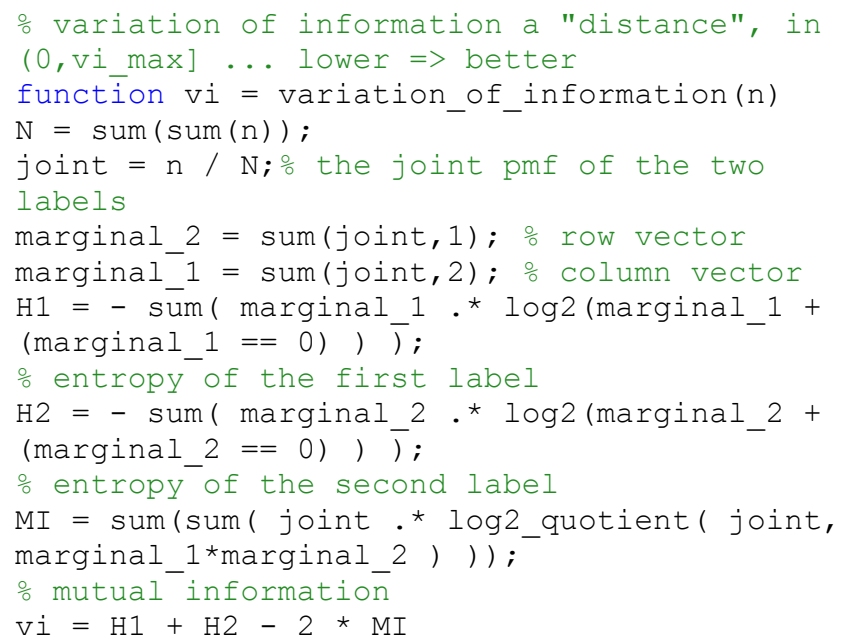

3. Blok diagram menghitung MSE (Mean Square Error) \& PSNR (Peak Signal to Noise Ratio) menggunakan Matlab pada Gambar 11. 


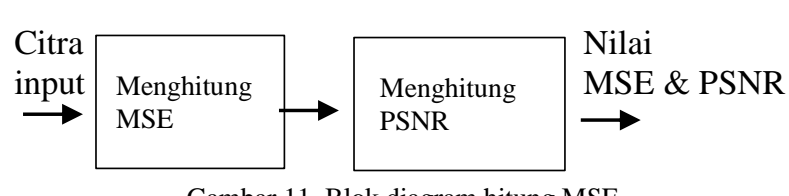

Gambar 11. Blok diagram hitung MSE

Berikut potongan source code menghitung MSE dan PSNR menggunakan Matlab :

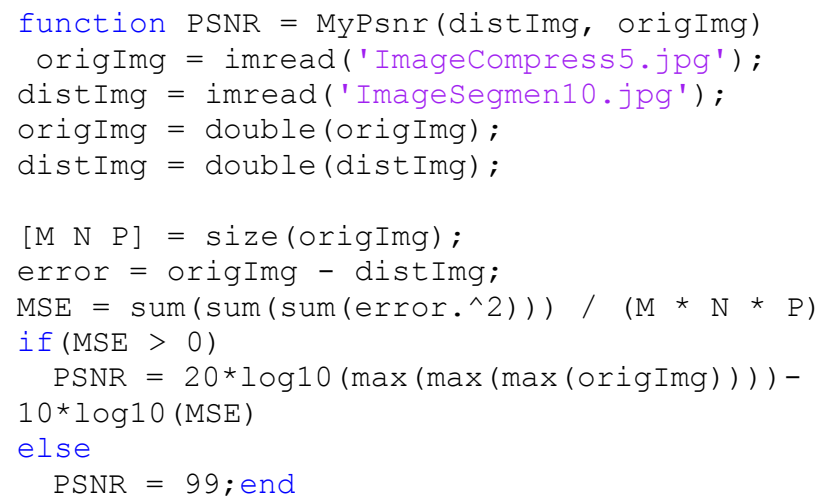

\section{HASIL DAN PEMBAHASAN}

Pada bagian ini membahas tentang hasil implementasi yang telah dilakukan. Pengujian performansi segmentasi dilakukan pada 10 citra MRI (otak \& payudara) baik kondisi normal maupun yang terdapat gangguan (lesi) yang telah dikompresi. Citra yang digunakan adalah citra dengan ekstensi JPG, PNG, dan BMP.

Tabel I. Citra MRI Input (Citra Kompresi) \& Citra Hasil Segmentasi

\begin{tabular}{|l|l|l|l|}
\hline No & $\begin{array}{c}\text { Citra Asli } \\
\text { (Kompresi) }\end{array}$ & $\begin{array}{c}\text { Citra } \\
\text { Segmentasi }\end{array}$ & \multicolumn{1}{c|}{ Deskripsi Citra Input } \\
\hline & & & \\
\hline
\end{tabular}

\begin{tabular}{|l|l|l|l|}
\hline 7 & & & \\
\hline 8 & & & $\begin{array}{l}\text { BMP, in }=887 \mathrm{~KB}, \text { Out }=885 \mathrm{~KB}, \\
\text { MRI (Payudara) terdapat lesi }\end{array}$ \\
\hline 9 & & & $\begin{array}{l}\text { MNG, in }=389 \mathrm{~KB}, \text { Out }=235 \mathrm{~KB}, \\
\mathrm{MRI}(\text { Payudara) terdapat lesi }\end{array}$ \\
\hline 10 & & & $\begin{array}{l}\text { JPG, in }=141 \mathrm{~KB}, \text { Out }=63,7 \mathrm{~KB}, \\
\mathrm{MRI}(\text { Payudara) kondisi normal }\end{array}$ \\
\hline & & & \\
\hline
\end{tabular}

Tabel II. Rasio Kompresi Citra Input

\begin{tabular}{|c|c|}
\hline $\begin{array}{c}\text { Citra Asli } \\
\text { (Kompresi) }\end{array}$ & $\begin{array}{c}\text { Rasio Kompresi } \\
(\%)\end{array}$ \\
\hline Citra 1 & 28,66 \\
\hline Citra 2 & 36,71 \\
\hline Citra 3 & 40,55 \\
\hline Citra 4 & 21,57 \\
\hline Citra 5 & 37,04 \\
\hline Citra 6 & 0,13 \\
\hline Citra 7 & 0,23 \\
\hline Citra 8 & 39,59 \\
\hline Citra 9 & 54,82 \\
\hline Citra 10 & 77,05 \\
\hline
\end{tabular}

Pada Tabel I menunjukkan bahwa Algoritme k-means mampu melakukan proses segmentasi pada citra MRI (Otak \& Payudara) yang sudah mengalami proses kompresi terlebih dahulu. Algoritme k-means mampu bekerja pada 3 ekstensi citra yang diusulkan pada penelitian ini (JPG, PNG, dan BMP). Secara visual algoritme $k$-means dapat melakukan proses segmentasi baik pada citra MRI yang kondisi normal maupun citra MRI yang mengalami lesi.

Sedangkan pada Tabel II menunjukkan rasio kompresi pada citra input. Pada tabel II memperlihatkan bahwa citra dengan ekstensi BMP memiliki rasio kompresi terkecil bila dibandingkan dengan JPG dan PNG. Ini menandakan citra BMP sangat sedikit kehilangan informasi dibandingkan dengan citra JPG dan PNG, sehingga tidak terjadi perubahan ukuran file yang sangat signifikan pada citra BMP.

Tabel III. Uji Performasi Hasil Segmentasi

\begin{tabular}{|c|c|c|c|c|c|}
\hline $\begin{array}{c}\text { Citra } \\
\text { Segmentasi }\end{array}$ & VOI & GCE & MSE & PSNR & $\begin{array}{c}\text { Waktu } \\
\text { Segmentasi } \\
\text { (detik) }\end{array}$ \\
\hline Citra 1 & 4,7856 & 0,3921 & 0,00104 & 15,68 & 2,09114 \\
\hline Citra 2 & 3,9120 & 0,0695 & 0,00254 & 13,64 & 3,51702 \\
\hline Citra 3 & 7,9564 & 0,6444 & 0,00162 & 15,60 & 2,27159 \\
\hline Citra 4 & 7,2993 & 0,5548 & 0,00059 & 20,41 & 1,71296 \\
\hline Citra 5 & 6,0968 & 0,5171 & 0,00484 & 10,54 & 2,88012 \\
\hline Citra 6 & 5,0696 & 0,0946 & 0,00182 & 15,59 & 6,56781 \\
\hline Citra 7 & 5,0154 & 0,0793 & 0,00196 & 12,56 & 7,15048 \\
\hline Citra 8 & 6,2224 & 0,1293 & 0,00325 & 12,01 & 3,17277 \\
\hline Citra 9 & 8,2078 & 0,5069 & 0,00449 & 9,45 & 1,60211 \\
\hline Citra 10 & 3,7568 & 0,2354 & 0,00185 & 12,67 & 1,29774 \\
\hline
\end{tabular}

Pada Tabel III menunjukkan bahwa hasil uji performansi VOI, GCE, MSE, dan PSNR serta waktu yang dibutuhkan 
untuk proses segmentasi citra pada ekstensi JPG, PNG, maupun BMP.

Tabel IV. Rata-Rata Perhitungan Uji Performansi

\begin{tabular}{|l|l|c|c|c|c|c|}
\hline No & $\begin{array}{c}\text { Ekstensi } \\
\text { Citra }\end{array}$ & VOI & GCE & MSE & PSNR & $\begin{array}{c}\text { Waktu } \\
\text { Segmentasi } \\
\text { (detik) }\end{array}$ \\
\hline 1 & JPG & 6,3504 & 0,4751 & 0,0024 & 14,06 & 1,975943 \\
\hline 2 & PNG & 5,0672 & 0,0994 & 0,0028 & 12,83 & 3,344895 \\
\hline 3 & BMP & 5,0425 & 0,0869 & 0,0019 & 14,08 & 6,859145 \\
\hline
\end{tabular}

Pada Tabel IV menunjukkan rata-rata hasil perhitungan analisis uji performansi segmentasi citra MRI VOI, GCE, MSE, dan PSNR serta waktu segmentasi dengan ekstensi yang berbeda.

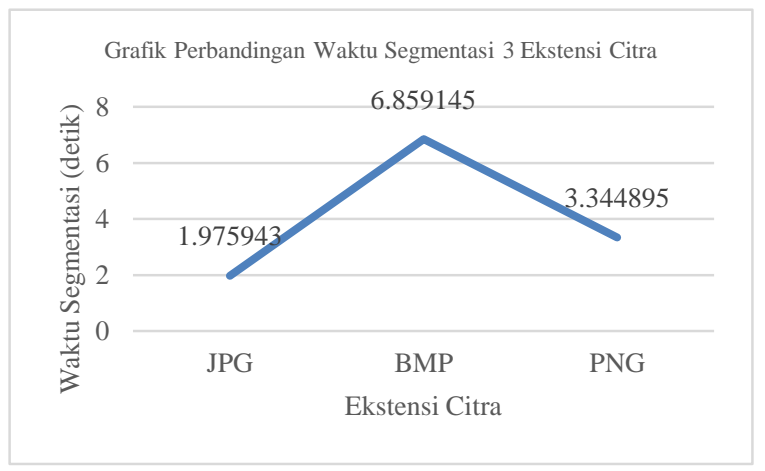

Gambar 12. Grafik perbandingan waktu segmentasi 3 ekstensi citra

Pada Gambar 12 menunjukkan grafik perbandingan waktu yang dibutuhkan dari masing-masing ekstensi citra untuk proses segmentasi. Dari Gambar 12 terlihat bahwa waktu yang dibutuhkan untuk proses segmentasi paling singkat adalah pada citra JPG yaitu sebesar 1,97543 detik, sedangkan yang paling lama adalah citra ekstensi BMP yaitu 6,895145 detik. Hal ini disebabkan karena resolusi untuk citra BMP jauh lebih besar dibandingkan dengan citra JPG dan BMP. Ini menandakan citra BMP lebih detail dibandingkan dengan citra JPG dan PNG.

Dari hasil segmentasi dan analisis kuantitatif menunjukkan bahwa secara keseluruhan citra dengan ekstensi BMP menunjukkan hasil yang lebih baik dibandingkan citra dengan ekstensi JPG dan PNG. Pada Gambar 13, Gambar 14, Gambar 15, dan Gambar 16 merupakan perbandingan uji performansi dari ketiga ekstensi citra.

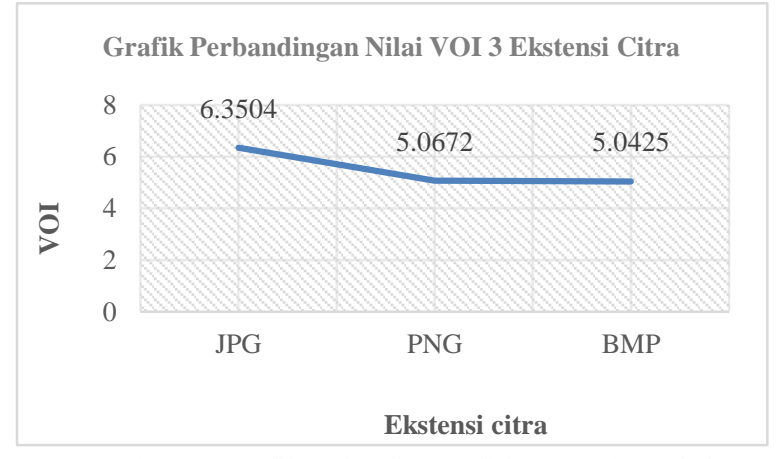

Gambar 13. Grafik perbandingan nilai VOI 3 ekstensi citra
Pada Gambar 13 menunjukkan grafik perbandingan nilai Variation of Information (VOI) dari ketiga ekstensi citra. Pada Variation of Information (VOI) berlaku dimana nilai yang lebih VOI rendah menunjukkan kesamaan yang lebih besar Antara citra asli dan citra segmentasi. Nilai VOI yang paling rendah adalah citra dengan ekstensi BMP yaitu 5,0425, citra PNG 5,0672, dan citra JPG 6,3504. Ini menandakan citra segmentasi pada ekstensi BMP menunjukan kesamaan yang lebih besar dengan citra asli.

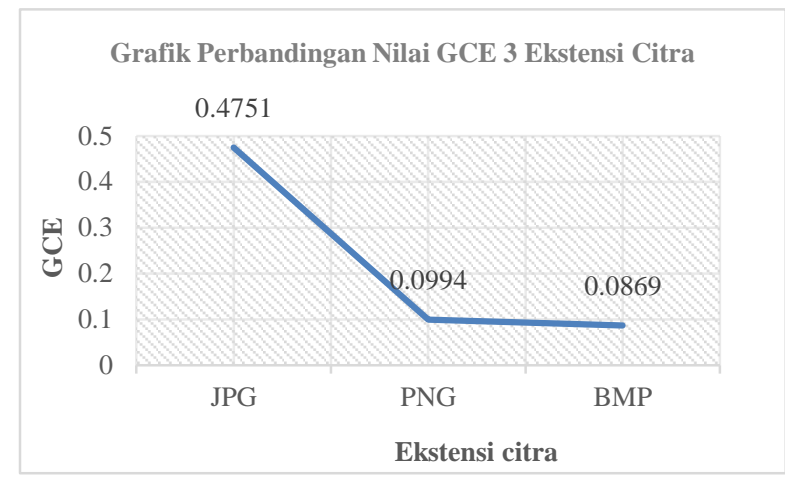

Gambar 14. Grafik perbandingan nilai GCE 3 ekstensi citra

Pada Gambar 14 menunjukkan grafik perbandingan nilai Global Consistency Error (GCE). Global Consistency Error (GCE) mengukur kesalahan segmentasi mengambil dua segmentasi S1 dan S2 sebagai input, dan menghasilkan output bernilai nyata dalam rentang $[0$ :: 1] di mana nol menandakan tidak ada kesalahan. Nilai GCE yang paling rendah adalah citra dengan ekstensi BMP yaitu 0,0869 , citra PNG 0,00994, dan citra JPG 0,4751. Ini menandakan citra segmentasi dengan ekstensi BMP memiliki kesalahan yang lebih kecil dibandingkan dengan citra ekstensi JPG dan PNG.

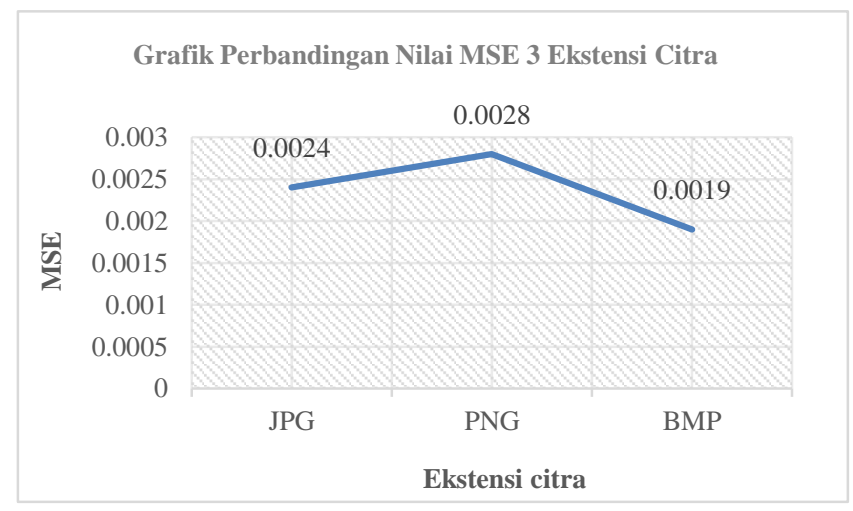

Gambar 15. Grafik perbandingan nilai MSE 3 ekstensi citra

Pada Gambar 15 menunjukkan grafik perbandingan nilai MSE (Mean Square Error) dari ketiga ekstensi citra. Dimana semakin kecil nilai MSE, semakin bagus hasil segmentasi. MSE hampir sama dengan GCE. Nilai MSE yang paling rendah adalah citra segmentasi dengan ekstensi 
BMP yaitu 0,0019, citra PNG 0,0028, dan citra JPG 0,0024. Ini menunjukkan bahwa citra dengan ekstensi BMP menghasilkan kualitas hasil segmentasi yang lebih bagus dibandingkan JPG dan BMP.

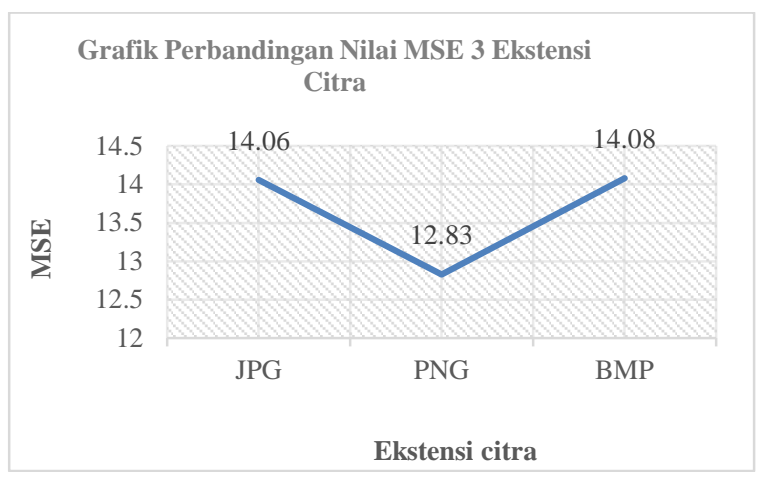

Gambar 16. Grafik perbandingan nilai PSNR 3 ekstensi citra

Pada Gambar 16 menunjukkan grafik perbandingan nilai PSNR (Peak Signal to Noise Ratio) dari ketiga ekstensi citra. Dimana Semakin besar nilai PSNR maka citra hasil segmentasi semakin mendekati citra aslinya. Sebaliknya, semakin kecil nilai PSNR semakin menurun kualitas citra tersebut. Citra segmentasi dengan ekstensi BMP menghasilkan nilai PSNR yang paling besar yaitu 14,08, citra PNG 12,83, dan citra JPG 14,06. Ini menandakan bahwa kualitas segmentasi dari citra ekstensi BMP jauh lebih baik dibandingkan JPG dan PNG.

\section{PENUTUP}

\subsection{Kesimpulan}

Berdasarkan hasil penelitian maka dapat disimpulkan bahwa program yang dirancang yaitu segmentasi citra MRI yang sudah melalui proses kompresi terlebih dahulu dengan algoritme $K$-Means berjalan dengan baik sesuai dengan apa yang direncanakan. Ini dapat terlihat dari hasil uji performasi dari ketiga ekstensi citra.

Secara visual algoritme $K$-Means dapat melakukan proses segmentasi pada citra MRI keadaan normal maupun citra MRI yang terdapat lesi. Citra hasil segmentasi dapat terlihat jelas mana area yang mengalami gangguan (lesi).

Algoritme K-Means yang diusulkan untuk proses segmentasi mampu bekerja pada citra dengan ekstensi JPG, PNG, mapun ekstensi BMP. Dari hasil penelitian, nilai VOI citra BMP memiliki nilai kesamaan yang lebih besar dengan citra aslinya dibandingkan citra JPG maupun citra PNG. Nilai GCE dan MSE yang dihasilkan dari ketiga ekstensi tersebut juga relatif kecil (mendekati 0), ini menandakan citra hasil segmentasi memiliki nilai kesamaan yang yang besar dengan citra aslinya. Selanjutnya citra BMP juga memiliki nilai PSNR yang paling besar dibandingkan dengan citra JPG dan citra PNG. Sedangkan waktu yang dibuthkan untuk proses segmentasi yang paling singkat yaitu pada citra dengan ekstensi JPG dan waktu yang paling lama untuk proses segmentasi adalah citra dengan ekstensi BMP

Pada penelitian yang akan datang dapat digunakan algoritme segmentasi citra dengan menggunakan algoritme yang lainnya seperti Fuzzy C Means untuk memperoleh citra hasil segmentasi yang memiliki tingkat keakurasian yang tinggi sehingga proses analisis lebih akurat dan tidak merugikan pihak pasien maupun pihak yang lain.

\section{UCAPAN TERIMA KASIH}

Penulis mengucapkan terima kasih kepada pihak-pihak yang telah memberi dukungan baik material maupun non material terhadap penelitian ini.

\section{DAFTAR PUSTAKA}

[1] D. Putra, Pengolahan Citra Digital, Yogyakarta: Penerbit ANDI, 2009.

[2] Nurhasanah, "Segementasi Jaringan Otak Putih, Jaringan Otak Abu-Abu, Dan Cairan Otak Dari Citra MRI Menggunakan Teknik K-Means Clustering," Jurnal Aplikasi Fiska, vol. 7, no. 2, pp. 90-95, 2011.

[3] T. Sutoyo, E. Mulyanto, V. Suhartono, O. D. Nurhayati, Wijanarto, Teori Pengolahan Citra Digital, Yogyakarta: Penerbit ANDI, 2009.

[4] B. R. Jipkate, V. V. Gohokar, "A Comparative Analysis of Fuzzy C-Means Clustering and K Means Clustering Algorithms," International Journal of Computational Engineering Research, vol. 2, pp. 737-739, 2012.

[5] A. S. B. Samma, R. A. Salam, "Adaptation of K-Means Algorithm for Image Segmentation," 2009.

[6] Preeti Panwar, Girdhar Gopal, Rakesh Kumar, "Image Segmentation using K-means clustering and Thresholding," International Research Journal of Engineering and Technology (IRJET), vol. 03, no. 05, pp. 1787-1793, 2016.

[7] Gonzalez,Woods, Digital Image Processing, 2nd Edition, Prentice Hall, 2002.

[8] B.Sathya, R.Manavalan, "Image Segmentation by Clustering Methods: Performance Analysis," International Journal of Computer Applications \& Information Technology, vol. 29, pp. 27-32, 2011.

[9] R. Sardana, "Comparitive Analysis of Image Segmentation Techniques," International Journal of Advanced Research in Computer Engineering \& Technology, vol. 2, pp. 2615-1619, 2013.

[10] M. Sharma, V. Chouhan, "Objective Evaluation Parameters of Image Segmentation Algorithms," International Journal of Engineering and Advanced Technology, vol. 2, pp. 84-87, 2012.

[11] I Wayan A. W. K., Afriliana K., "Penerapan Algoritma K-Means pada Kompresi Adaptif Citra Medis MRI," INFORMATIKA, vol. 11, no. 2, pp. 139-151, 2015.

[12] Dika Asoka Masatu, Indah Soesanti, Hanung Adi Nugroho, "Penerapan Algoritma Kompresi JPEG dan Metode Fuzzy C Means pada Kompresi 
Citra Berbasis Entropi," Jurnal Penelitian Teknik Elektro dan Teknologi Informasi, vol. 1, no. 1, pp. 7-11, 2014.

[13] S. M. Aqil Burney, Humera Tariq, "K-Means Cluster Analysis for Image Segmentation," International Journal of Computer Applications, vol. 96, no. 4, pp. 1-8, 2014.

[14] Poonam fauzdar, Sujata Kindri, "Comparitive Analysis Of K Means And Fuzzy C Means Algorithm," International Journal of Engineering Research \& Technology (IJERT), vol. 2, no. 6, pp. 2088-2095, 2013.

[15] S. panda, "Color Image Segmentation Using K-means Clustering and Thresholding Technique," IJESC, pp. 1132-1136, 2015.

[16] Anju Bala, Aman Kumar Sharma, "Color Image Segmentation using K-Means Clustering and Morphological Edge Detection Algorithm," International Journal of Latest Trends in Engineering and Technology (IJLTET), pp. 48-55, 2016.

[17] S. J. Saida, L. Srinivas, R. Sivaram, "An Efficient K-Means and C-Means Clustering Algorithm for Image Segmentation," International Journal of Science and Applied Information Technology, vol. 1, no. 5, pp. 84-87, 2012.

[18] R. S. Kabade, M. S. Gaikwad, "Segmentation of Brain Tumour and Its Area Calculation in Brain MR Images using K-Mean Clustering and Fuzzy C-Mean Algorithm," International Journal of Computer Science \& Engineering Technology, vol. 4, pp. 524-531, 2013.

[19] Jiawei Han, Micheline Kamber, Jian Pei, Data Mining Concept and Techniques Third Edition, Morgan Kaufmann, 2012.

[20] Jiawei Han, Micheline Kamber, Data Mining: Concepts and Techniques Second Edition, Diane Cerra Publisher, 2006.

[21] M. North, Data Mining for the Masses, 2012.

[22] I. Soesanti, A. Susanto, T. S. Widodo, M. Tjokronegoro, "Analisis Komputasi pada Segmentasi Citra Medis Adaptif Berbasis Logika Fuzzy Teroptimasi," Forum Teknik, vol. 33, no. 2, pp. 89-96, 2010.

[23] Irwanto, Yudhi Purwananto, Rully Soelaiman, "Optimasi Kinerja Algoritma Klasterisasi K-Means untuk Kuantisasi Warna Citra," JURNAL TEKNIK POMITS, vol. 1, no. 1, pp. 1-6, 2012.

[24] Dika Asoka Masatu, Indah Soesanti, Hanung Adi Nugroho, "PENERAPAN ALGORITMA KOMPRESI JPEG DAN METODE FUZZY CMEANS PADA KOMPRESI CITRA BERBASIS ENTROPI," Jurnal Penelitian Teknik Elektro dan Teknologi Informasi, vol. 1, no. 1, pp. 7-11, 2014.

[25] S. Jani, "An Efficient K-Means and Fuzzy CMeans Clustering Algorithm for Image,"
International Journal of Engineering Research \& Technology (IJERT), vol. 1, no. 5, 2012. 